\title{
Dollars and demographics
}

\author{
by Paul McKellips
}

Do Americans have opinions about lab animal research? You could say that.

Since August 2010, the Foundation for Biomedical Research has commissioned monthly tracking polls through Zogby to measure public attitudes on the humane and responsible use of animals in biomedical research. In January 2014 we will take our forty-second consecutive poll.

Before poll respondents are asked about animal research, Zogby collects demographic information including gender, age, political party, political ideology, education level, geographical location, marital status and other characteristics.

Before they even answer the key question-do you agree or disagree with medical and scientific research that requires lab animals? - we already know a lot about the people behind the opinions.

We conducted our first national poll in November 2009 with a survey sample of more than 2,100 people. We were discouraged to learn that only $49.9 \%$ of the American public supported research that required animals.

Thanks to the specific demographic information collected, we knew exactly which segments of the population disagreed with research requiring animals, and we decided to target these segments with information and advertising. Regular citizens who are opposed to animal research are not typically extremists; they simply disagree. We used 100-person focus groups, armed with interactive clickers, to test which research messages would change their minds.

In August 2010, simultaneous with the first monthly tracking poll, we launched the national ResearchSaves campaign, which included TV commercials, outdoor billboard advertising and a daily 60 -second radio show that was aired on more than 3,500 AM stations across the country. The cause-and-effect results were nothing

McKellips is Executive Vice President of the Foundation for Biomedical Research in Washington, DC.

TABLE 1 | Overall responses (\%) to the question "Do you agree or disagree with medical and scientific research that requires lab animals?" in monthly polls during 2013.

$\begin{array}{lllllllllll} & \text { Jan } & \text { Feb } & \text { Mar } & \text { Apr } & \text { May } & \text { Jun } & \text { Jul } & \text { Aug } & \text { Sep } & \text { Oct } \\ \text { Agree } & 47 & 52 & 47 & 48 & 48 & 48 & 46 & 47 & 45 & 49 \\ \text { Disagree } & 40 & 39 & 42 & 39 & 34 & 38 & 40 & 42 & 42 & 38 \\ \text { Not sure } & 11 & 9 & 11 & 13 & 19 & 14 & 14 & 12 & 14 & 13\end{array}$

short of amazing. Public support grew for 29 consecutive months until it peaked in November 2012.

In less than three years, public support for the humane and responsible use of animals in research rose from $49.9 \%$ to a high of $62.7 \%$.

That's a success story, right? Well, yes and no. In the nonprofit world of fundraising, success can be one's worst enemy. The more a problem seems to go away, the less urgency seems to be felt to keep funding a solution.

Regardless, with critical information targeted at the precise demographic segment that needed more information about animal research, we were able to move the needle of public opinion quite easily.

That was until December 2012.

For the first 29 months of the ResearchSaves campaign, our messaging was directed at the most at-risk demographic of all: women, 29-54 years old, Democrat with liberal ideology. But with all of the public discussion centered on the 'fiscal cliff' debate, debt ceilings and the threat of sequester, we lost another entire demographic segment: men, 29-54 years old, Republican with conservative ideology. Democrat women wanted to protect the animals at all costs. Republican men wanted to protect taxpayer dollars at all costs.

Yet no one was asking about the cost of under-funded research or animal research conducted offshore. No one was asking about the opportunity cost of airlines refusing to ship nonhuman primates for research. Government research funding has been slashed. Animal rights groups like PETA, HSUS and PCRM raked in more than $\$ 160$ million in 2013 , as public support for the humane and responsible use of animals in research at American universities, institutes, contract research organizations and biotechnology and pharmaceutical companies tanked.

For most of 2013, public support stood at a blended $47.7 \%$ while strong opposition reached $39.4 \%$ (Table 1 ).

Public attitudes among the genders leveled out with $60 \%$ of men supporting animal research and only $34.2 \%$ of women agreeing. Most notably, Republican support (55.4\%) started to climb at the end of 2013 while Democrat support (45.2\%) continued to fall. As for ages, the most surprising opinions came from the oldest among us, who also happen to be the most dependent on medicines and vulnerable to disease. The youngest (ages 18-29) predictably registered the least support for animal research at $45 \%$, the middle agers (30-49 years old) and the mature citizens (50-64 years old) had the highest support at $47.2 \%$, while senior citizens (ages 65+) - with children grown and companion pets on their lapssupported animal research at only $46 \%$.

Clearly, with sufficient funding, the biomedical research community could win the public opinion war. But with vertical downward pressure on funding, research and development budgets and profit margins, it's hard to believe that enough money will be thrown at the problem in time.

That leaves us with grassroots outreach. If we rise up and tell our stories as advocates for research, we can make an incremental difference at the local level. Remember that the next time you're at a party or out for dinner with friends, whether Democrat women or Republican men, and tell them all about research. 